\title{
Romanian Second Language Learners of English Requests and Apologies
}

\author{
Hasan Aydin \\ International Kurdish Research Center (UKAM/IKRC), Istanbul, Turkey \\ Email: hasan9a@yahoo.com \\ Christopher Koch \\ University of Nevada, Reno, USA
}

\begin{abstract}
Despite the wealth of literature generated over the past three decades on requests and apologies as a speech act, cross-cultural requests and apologies have been neglected as a research topic in the international press. This cross-sectional mixed method study was designed to examine requests and apologies with the longterm goal of designing a valid teaching application for the ESL and EFL teachers. There were 80 participants that included male and female students within the first through seventh grade population of the International School of Cluj-Napoca, Romania (ISC). Data was collected within the Modified Cartoon Oral Production Tools (MCOPT), which includes 16 cartoon drawings depicting situations in which two characters interact. The research data was gathered in a heterogeneous and a typical setting within north western Romania. The resulting analysis is that the sophistication of speech acts increases with age more than with length of study.
\end{abstract}

Index Terms—requests, apologies, second language, mixed-method, Romania

\section{INTRODUCTION}

When people talk about language, they generally refer to a system of communication using arbitrary signals. However, a language is more than just words or grammar. A language consists of speech acts or functional performances, such as asking a question, apologizing or making a request. These are culturally constructed and, therefore, vary from language to language. So, when a speaker learns a second language, he or she must learn more than just the words or grammar; he or she must also learn enough about the culture to perform these speech acts correctly. Speech acts are something Hymes (1972), who developed the concept in the mid 1960s, referred to as communicative competence. In order to gain this communicative competence, a speaker must gain sociolinguistic competence or knowledge of the sociocultural rules of the language's speakers. These rules establish the appropriateness of a speech act within a certain context. When greeting someone in a very formal situation, an American might say, Hello, how are you? or Nice to see you again, but if he were meeting a friend in an informal situation it would be much more appropriate to say $\mathrm{Hi}$, or Hey, whatcha been doing?

The study of communicative competence is called pragmatics. "Pragmatics is the study of language from the point of view of users, especially of the choices they make, the constraints they encounter in using language in social interaction and the effects their use of language has on other participants in the act of communication" (Crystal, 1997, p. 301). Leech (1983) presents pragmatics as interpersonal rhetoric - social actors who are not just trying to accomplish a goal, but attending to their interpersonal relationships with others while conducting the activities of life. According to BlumKulka, House and Kasper (1989), there are two aspects of pragmatics. The first, pragmalinguistics, deals with the words available or linguistic resources that enable a speaker to perform a speech act. Here, syntax and grammar play significant roles in the speech act. Second is sociopragmatics, which examines the use of speech acts in social contexts and the social factors that affect them. This is the aspect where familiarity with an individual or their social status influences the application of the speech act.

According to LoCastro (2003), each speech act has an inherent benefit for the speaker, listener, or both. The determination of these benefits is based on the face needs of the participants. Face refers to a person's "public selfimage" (LoCastro, p. 110). A speech act can add to, take away, or have no effect on a person's face. These effects of speech acts result in a choice of strategy or a careful consideration of how the speech act will be performed. These strategies are chosen based on the potential for face loss of either participant, or the weight of imposition. The risk of face loss is gauged based on power relationships, social distance, and individual judgments of imposition upon the speaker or addressee. These, in turn, are determined by variables such as social status, age, gender, and occupation, that can influence which strategy a speaker will use.

Brown and Levinson's (1987) theory of pragmatic strategy suggests that there are three ways an individual can perform a speech act. One can either perform the speech act directly (with or without attempting to lessen the threat to face), perform it indirectly, or not perform it at all. For example, a direct request may attempt to lessen the threat to face: "May I borrow a pencil?" or without regard for face: "Let me use that pencil for a second." An indirect request would 
be "I'm sorry, I don't have a pencil." Not performing the act of requesting a pencil at all could look like this: "I'm sleepy."

Brown and Levinson (1987) also identify two types of politeness: positive and negative. Positive politeness is concerned about social approval, "If you would like, we can go to lunch. I will pick you up at 11:30." Negative politeness results from increased social distance and attempts to avoid adding any imposition. This would sound like, "I am sure you are too busy to go to lunch with me." The same factors that determine the choice of strategy will also affect the politeness of the speech act.

From another perspective, Blum-Kulka \& Kasper (1993) define pragmatics in terms of second language learners, (SLL) or interlanguage pragmatics, described as "the study of the nonnative speakers' use and acquisition of linguistic action patterns in a second language" (p. 3). For a SLL, familiarity with the language and culture, as well as the ability to recognize the factors of power, social distance and imposition, and what these factors mean, are additional influences on the ability to perform a speech act with native-like competency. In addition, the pragmatics acquired in the speaker's first language (L1) may transfer to the speaker's second language. This is called pragmatics transfer and is central to the study of interlanguage pragmatics (ILP). The SLL's pragmatics awareness (knowledge of the rules of appropriate speech act performance), as well as pragmatics performance (actual use of the rules of appropriate speech act performance) in the second language across various social contexts, and the factors which affect their acquisition, are also very salient to ILP.

Many researchers (Ellis, 1992; Kasper \& Schmidt, 1996; Olshtain \& Cohen, 1989; Trosberg, 1995) have studied interlanguage pragmatics' (ILP) use of language to shape second language learners' speech acts of requests and apologies. A request is an act that is frequently performed in daily interaction across societies, and is a face-threatening act (Brown \& Levinson, 1987), in which the speaker asks the hearer to perform an act beneficial to the speaker. BlumKulka et al. (1989) and Olshtain and Cohen (1983) define apology speech acts as covering a range of strategies. They have identified five specific types: 1) illocutionary force indicating device (IFID)- i.e. sorry, apologize, regret, excuse 2) an explanation or account of the cause 3) an expression of the speaker's responsibility 4) an offer of repair, and 5) a promise of forbearance. As suggested by Ely \& Gleason (2006), "Apologies are remarkable linguistic and social tools. They can restore damaged relationships; mitigate loss of face, and preserve social standing” (p. 599). This study is interested in learning if there are any relationships within the two subgroups, requests and apologies, of speech acts. For example, as amount of (time) English education level of second language learners increases, how does the level of indirectness change?

Blum-Kulka (1991), Kasper and Blum-Kulka (1993) and Ellis (1994) have all studied the dynamics of variability of speech acts between L1 and L2 learners. They found requests to be one of the first productive illocutionary acts performed by learners. These request skills are acquired as a result of communicative needs rather than instruction. Additionally, they noted that SLLs tend to be more verbose, while native speakers are more succinct and get the interaction over with quickly.

Researchers acknowledge that L1, social and cultural setting, individual differences, linguistic competence, age, and length of time in formal study of English all influence SLLs. Achiba (2003) points out in his research that pragmatic reasoning begins to develop around age 9 and, by age 11, the child has accuracy and consistency. Hassall (2003) suggests that L1 pragmatic transfer occurs out of necessity, while Kobayashi and Rinnert (2003) state pragmatic transfer cannot be definitively established by looking at a single aspect of a speech act. Schauer (2004), though stating her data is limited because of a small number of participants, suggests we need to consider that some people prefer to be more direct.

The value of this research is, in the Teaching English to Speakers of Other Languages (TESOL) field, its potential for predictability. For example, different L1s produce specific styles of ILP that help us to predict and develop teaching styles for SLLs. Each request and apology is comprised of an innate acquired formula, with a range of variations. This research is interested in tracking the use of these variations (Beebe \& Takahashi, 1989). The sub-section of apologies is of interest because of its frequent use within a culture. When accessed inappropriately (and a social or linguistic error occurs), problems occur for one or more people (Brown \& Levinson, 1987). Miscommunication is often imprecisely diagnosed as ill-mannered behavior on the part of the hearer. With empirical data of how SLLs execute specific speech acts, our research may lead to more effective teaching applications to help move SLLs towards native-like pragmatic behavior and competence (Hassell, 2003).

\section{METHOD}

\section{A. Setting}

Data was collected within individual classrooms at The International School of Cluj (ISC), a not-for-profit school within the city limits of Cluj-Napoca, Romania. This school was selected for the research project because of language variations, the focus on English education for the kindergarteners and the ISC's striving for best practices which includes the use of teachers with a higher degree of academic training. The school is a bi-lingual Romanian-English, or Romanian-German educational program. ISC has two different academic tracks, one for foreign students and one for native Romanians, to meet the needs of its diverse students. The current enrollment is 115 students with $80 \%$ of the 
student body being native Romanian. The other $20 \%$ come from language backgrounds including Hungarian, Turkish, Farsi, Dutch, Japanese, Arabic, and German.

\section{B. Participants}

The participants for this cross-sectional study included all 80 of the students from the ISC who were involved in some degree of English language learning within the academic setting, and none of whom spoke English as a first language. The participants included male and female students within the first through seventh grade population of ISC. All participants remained anonymous.

\section{Research Questions}

What is the range of pragmalinguistic and sociopragmatic proficiency in English as evidenced in the request and apology strategies of school children studying English as a non-native language?

1) Does length of time of English instruction show a significant relationship with indirectness of requests?

2) Does length of time of English instruction show a significant relationship with formula of apologies?

3) Does age of speaker correlate with indirectness of requests?

4) Does age of speaker correlate with formula of apologies?

\section{Data Collection}

Data was collected by administering the Cartoon Oral Production Tools (COPT) developed by Rose (2000) and adapted by the researchers. Our instrument is called the Modified Cartoon Oral Production Tools (MCOPT), which includes 16 cartoon drawings depicting situations in which two characters interact. The original instrument contained 30 separate cartoon drawings, each designed to elicit an apology, request or compliment. The only change to the original instrument was the removal of all 14 compliment cartoons. For the purposes of this study, the cartoons for compliments were not used. Each student participant was shown a cartoon and asked to indicate what he or she would say in a particular situation. Each of the cartoons in MCOPT was designed to elicit requests or apologies.

After the cartoons were administered and data collected, demographic data was collected to test the effect of age, the participant's academic grade, and years of English language education experience on the levels of indirectness of apologies and requests.

\section{E. Procedures}

The research team was composed of a presenting researcher and a note-taker. After obtaining permission from the ISC director, teachers, and students, the team administered the instrument to individual volunteers who were students at ISC (participant). All communications with the participants were conducted in English. The researcher presented the MCOPT and the note-taker transcribed the participant's responses. The presenting researcher read the instructions to the participant from a written script. This method ensured that interactions between researchers and participants were consistent. The presenting researcher then showed the first cartoon of the MCOPT to the participant. The participant read the caption to themselves and responded orally, in English, about the cartoon with the request or apology that he or she would use in the same situation. In the event that a student did not begin answering with the first cartoon, which may indicate confusion regarding the procedure or difficulty formulating responses, the presenting researcher read the caption aloud and asked the student what he or she would say in the same situation. This procedure was only to be used for the first cartoon. With the remaining cartoons, participants were given instructions to say "pass" for cartoons for which they were unable to or unwilling to provide a response. Any wait-time for responses was determined by the participant. Wait-time is a concept identified in the early 1970's as the period of silence that follows a teacher's question and students' completed responses. The team found the entire process required approximately 8 minutes, with no interviews exceeding 10 minutes.

After the instrument was administered, demographic data was collected, including date of birth, current grade level, number of years studying English, and nationality. The participant was asked the demographic questions after the cartoon responses, to reduce the possibility of participant anticipation based on interactions with the researcher.

\section{F. Analysis}

Statistical analysis of the data was carried out using SPSS for Windows, 16.0. Descriptive statistics were used to compute the frequency of formula (utterance) use. Two types of statistical tests were employed to examine the data; $t$ tests, and Pearson's correlations. For all analyses, the alpha level was set at $\leq .05$.

The unit of analysis is the verbal comments/utterances, supplied by the participants. Each request utterance was coded using the categories developed by Blum et al. (1989), scored on a scale of 1 - 9 for levels of directness. The apology utterances were coded using categories also developed by Blum et al. (1989), scored on a scale of 1 - 5 for potential strategies. The coding data was based on a narrow and non-problematic range, making the need for a second rater unnecessary. Demographic data, specifically length of formal English education and academic grade level, was analyzed to examine group differences via $t$-tests. The units of difference produced by the $t$-tests were standardized and examined to find a moderate effect size using Cohen's $d=0.5$. In addition to coding, the order of semantic formulas 
used in each speech act was noted, which identifies the level of indirectness; for example, the differences between "Please can I borrow your pencil?" and "Can I borrow your pencil please?"

\section{RESUltS}

\section{A. Requests}

The ten request cartoons were analyzed based on the first response, which was coded (Cartoon 1) as direct (e.g., Give me school stuff.), conventionally indirect (e.g., Can you buy me some stationery?), and hint (e.g., Do you want to buy some stationery?). Each participant was told they could opt-out by either saying, "pass" or simply turning the page and moving to the next cartoon. There were not sufficient numbers of second or third responses to allow for statistical analysis. Table One presented the data based on frequencies, showing Direct requests were the favored utterance.

TABLE ONE

ALL CARTOONS, REQUEST ONE

\begin{tabular}{|ll|l|l|l|l|}
\hline & & Frequency & Percent & Valid Percent & Cumulative Percent \\
\hline Valid & Direct & 426 & 53.3 & 55.5 & 55.5 \\
& Conventional indirect & 316 & 39.5 & 41.1 & 96.6 \\
& Hint & 26 & 3.3 & 3.4 & 100.0 \\
& Total & 768 & 96.0 & 100.0 & \\
Missing & Opt out & 32 & 4.0 & & \\
Total & & 800 & 100.0 & & \\
\hline
\end{tabular}

TABLE TWO

ALL CARTOONS, REQUEST ONE * ACADEMIC GRADE LEVEL CROSSTABULATION

\begin{tabular}{|c|c|c|c|c|c|c|c|c|c|c|}
\hline & & & \multicolumn{7}{|c|}{ academic grade level } & \multirow{2}{*}{$\begin{array}{l}\text { Total } \\
1.00\end{array}$} \\
\hline & & & 1.00 & 2.00 & 3.00 & 4.00 & 5.00 & 6.00 & 7.00 & \\
\hline \multirow[t]{6}{*}{$\begin{array}{l}\text { All cartoons, } \\
\text { request one }\end{array}$} & Direct & Count & 18 & 32 & 77 & 172 & 53 & 44 & 30 & 426 \\
\hline & & $\begin{array}{l}\% \text { within } \\
\text { academic grade } \\
\text { level }\end{array}$ & $\begin{array}{l}94.7 \\
\%\end{array}$ & $\begin{array}{l}69.6 \\
\%\end{array}$ & $\begin{array}{l}56.2 \\
\%\end{array}$ & $\begin{array}{l}72.3 \\
\%\end{array}$ & $\begin{array}{l}49.1 \\
\%\end{array}$ & $36.7 \%$ & $\begin{array}{l}30.0 \\
\%\end{array}$ & $55.5 \%$ \\
\hline & $\begin{array}{l}\text { Conventional } \\
\text { indirect }\end{array}$ & Count & 1 & 9 & 58 & 58 & 47 & 73 & 70 & 316 \\
\hline & & $\begin{array}{l}\% \text { within } \\
\text { academic grade } \\
\text { level }\end{array}$ & $5.3 \%$ & $\begin{array}{l}19.6 \\
\%\end{array}$ & $\begin{array}{l}42.3 \\
\%\end{array}$ & $\begin{array}{l}24.4 \\
\%\end{array}$ & $\begin{array}{l}43.5 \\
\%\end{array}$ & $60.8 \%$ & $\begin{array}{l}70.0 \\
\%\end{array}$ & $41.1 \%$ \\
\hline & Hint & $\begin{array}{l}\text { Count } \\
\% \text { within }\end{array}$ & 0 & & 2 & 8 & 8 & 3 & 0 & 26 \\
\hline & & $\begin{array}{l}\text { academic grade } \\
\text { level }\end{array}$ & $.0 \%$ & $\begin{array}{l}10.9 \\
\%\end{array}$ & $1.5 \%$ & $3.4 \%$ & $7.4 \%$ & $2.5 \%$ & $.0 \%$ & $3.4 \%$ \\
\hline \multirow[t]{2}{*}{ Total } & & Count & 19 & 46 & 137 & 238 & 108 & 120 & 100 & 768 \\
\hline & & $\begin{array}{l}\% \text { within } \\
\text { academic grade } \\
\text { level }\end{array}$ & $\begin{array}{l}100.0 \\
\%\end{array}$ & $\begin{array}{l}100.0 \\
\%\end{array}$ & $\begin{array}{l}100.0 \\
\%\end{array}$ & $\begin{array}{l}100.0 \\
\%\end{array}$ & $\begin{array}{l}100.0 \\
\%\end{array}$ & $\begin{array}{l}100.0 \\
\%\end{array}$ & $\begin{array}{l}100.0 \\
\%\end{array}$ & $100.0 \%$ \\
\hline
\end{tabular}

The influence of grade level on indirectness of request utterance was predictably obvious. We believe, at least initially, that this is a result of cognitive development instead of pragmatic developmental trends. The research question was does the relationship between grade level and length of English language education show a correlation?

\begin{tabular}{|c|c|c|c|c|}
\hline \multicolumn{5}{|c|}{$\begin{array}{l}\text { TABLE THREE } \\
\text { Correlations }\end{array}$} \\
\hline & & $\begin{array}{l}\text { All cartoons, } \\
\text { request one } \\
\text { (means, } \\
\text { from original } \\
\text { variables) }\end{array}$ & $\begin{array}{c}\text { academic } \\
\text { grade level }\end{array}$ & $\begin{array}{l}\text { years of } \\
\text { academic } \\
\text { English } \\
\text { instruction }\end{array}$ \\
\hline \multirow{3}{*}{$\begin{array}{l}\text { All cartoons, request } \\
\text { one (means, from } \\
\text { original variables) }\end{array}$} & Pearson Correlation & 1 & $.424^{\star \star}$ & -.001 \\
\hline & Sig. (2-tailed) & & .001 & .995 \\
\hline & $\mathrm{N}$ & 60 & 60 & 60 \\
\hline \multirow[t]{3}{*}{ academic grade level } & Pearson Correlation & $.424^{\star \star}$ & 1 & $.313^{\star \star}$ \\
\hline & Sig. (2-tailed) & .001 & & .005 \\
\hline & $\mathrm{N}$ & 60 & 80 & 80 \\
\hline \multirow{3}{*}{$\begin{array}{l}\text { years of academic } \\
\text { English instruction }\end{array}$} & Pearson Correlation & -.001 & $.313^{\star \star}$ & 1 \\
\hline & Sig. (2-tailed) & .995 & .005 & \\
\hline & $\mathrm{N}$ & & & 80 \\
\hline
\end{tabular}


There is a significant positive correlation between grade level and sophistication of request (indirectness) overall one $(r=.424, p=.001)$, meaning that when students are in higher grades they will perform better, but no relationship between performance and years in studying English (Table Three).

\section{B. Apologies}

Distinct from requests, the six apologies were coded as having multiple strategies. The main strategy was labeled as the first utterance. Any additional utterance was coded as an adjunct. Each utterance is identified as one of five specific types: 1) illocutionary force indicating device (IFID)- sorry, apologize, regret, excuse 2) an explanation or account of the cause (She pushed me!) 3) an expression of the speaker's responsibility (I didn't mean to.) 4) an offer of repair (I will buy you a new one.), and 5) a promise of forbearance (I will never do this again.). Apologies did not demonstrate a significant relationship at all for all six apology cartoons, even when we looked separately at each apology cartoon.

The frequency table (Table Four) shows IFID were used in the first response 86.7\% of the time. This is a pattern observed by other researchers (Rose, 2000). This reliance on IFIDs could be a result of mastery of that specific speech act formula versus individualized decision making for each cartoon.

TABLE FOUR

ALL CARTOONS, APOLOGY ONE

\begin{tabular}{|ll|l|l|}
\multicolumn{4}{c}{ ALL CARTOONS, APOLOGY ONE } \\
\hline & & Frequency & Percent \\
\hline Valid & IFID & 415 & 86.5 \\
& Other & 46 & 9.5 \\
& Total & 461 & 96.0 \\
Missing & Opt out & 19 & 4.0 \\
Total & & 480 & 100.0 \\
\hline
\end{tabular}

The frequency breakdown of apologies and supporting adjuncts did present a range of utterance; however, there was neither a clear pattern of type nor any notable relationship with grade level or length of English language education. This occurrence may be a result of the influence of the lack of homogeneity within the participants.

TABLE FIVE

ALL CARTOONS, APOLOGY ONE

\begin{tabular}{|ll|l|l|l|l|}
\hline & & Frequency & Percent & Valid Percent & Cumulative Percent \\
\hline Valid & IFID & 415 & 86.5 & 90.0 & 90.0 \\
& explanation & 15 & 3.1 & 3.3 & 93.3 \\
& responsibility & 12 & 2.5 & 2.6 & 95.9 \\
& repair & 19 & 4.0 & 4.1 & 100.0 \\
& Total & 461 & 96.0 & 100.0 & \\
Missing & opt out & 19 & 4.0 & & \\
Total & & 480 & 100.0 & & \\
\hline
\end{tabular}

\section{CONCLUSION}

The research data was gathered in a heterogeneous and atypical setting within north western Romania. The crosssectional study was designed to examine requests and apologies with the long-term goal of designing a valid teaching application for the ESL teacher. The research team encountered many of the hurdles that researchers meet - the need for field revisions, time delays, more questions than answers, and how to examine the data in a manner which maintains its authenticity.

It is conjecture that the data, and its variations, is greatly influenced by a variety of independent variables (e.g. heritage language, exposure to English in other settings, length of time attending ISC, point in cognitive development when formal English education commenced, and pedagogy of English instruction). The team was unable to carry out the background questions, which would have addressed some of these, factors influencing pragmatic development because we did not have the foresight to present them to the IRB prior to traveling to Romania to begin data collection.

The data analysis presented what would be expected, the sophistication of speech acts increases with age. There does not appear to be a strong relationship with length of formal English instruction. The motivation of this study was to examine influences on interlanguage pragmatic development with the long-term intent of program development. At this point, broad statements regarding teaching $\mathrm{L} 2$ pragmatics cannot be made.

Further study is going to be applying this study design in Eastern Europe, returning to Cluj-Napoca, Romania, as well as expanding our data collection to the Romanian capital, Bucharest. Each application allows us further refinement and further speculation. It is hoped to develop data collection that may demonstrate greater contrast. Key to this series of data gathering is developing a series of activities and overall application that can enhance pragmatic competence for English language learners, and perhaps, a second language-teaching model.

\section{REFERENCES}


[1] Achiba, M. (2003). Learning to request in a second language: A study of child interlanguage pragmatics. Clevedon, UK: Multilingual Matters, LTD.

[2] Bardovi-Harlig, K., Hartford, B.A., Mahan-Taylor, M.R., Morgan, M.J., \& Reynolds, D.W. (1991). Developing pragmatic awareness: Closing the conversation. In T. Hedge \& N. Whitney (Eds.), Power, pedagogy, and practice (pp. 4-15). Oxford: Oxford University Press.

[3] Beebe, L., \& Takahashi, T. (1989). Sociolinguistic variation in face-threatening speech acts: Chastisement and disagreement. In M. Eisenstein (Ed.), The dynamic interlanguage: Empirical studies in second language variation (pp. 199-218). New York: Plenum Press.

[4] Blum-Kulka, S. (1987). Indirectness and politeness in requests: Same or different? Journal of Pragmatics, 11, 131-146.

[5] Blum-Kulka, S. (1991). Interlanguage Pragmatics: The case of requests. In R. Philipson, E. Kellermen, L. Selinker, M. Sharwood Smith \& M. Swain (Eds.), Foreign/Second Language Pedagogy (pp. 255-271). Clevedon, UK: Multilingual Matters.

[6] Blum-Kulka, S., House, J., \& Kasper, G. (1989). Investigating cross-cultural pragmatics: An introduction overview. In S. Blum-Kulka, J. House \& G. Kasper (Eds.), Cross-cultural pragmatics: Requests and apologies (pp. 1-34). Norwood, NJ: Ablex.

[7] Blum-Kulka, S., \& Kasper, G. (1993). Interlangauge pragmatics. Oxford: Oxford University Press.

[8] Bou-Franch, P., \& Garcés-Conejos, P. (2003). Teaching linguistic politeness: A methodological proposal. International Review of Applied Linguistics, 41(1), 1-22.

[9] Brown, P., \& Levinson, S.C. (1987). Politeness: Some universals in language usage. New York: Cambridge University Press.

[10] Chaudron, C. (1988). Second language classrooms: Research on teaching and learning. Cambridge: Cambridge University Press.

[11] Crystal, D. (Ed.). (1997). The Cambridge encyclopedia of language ( $2^{\text {nd }}$ ed.). New York: Cambridge University Press.

[12] Ellis, R. (1992). Learning to communicate in the classroom: A study of two language learners' requests. Studies in Second Language Acquisition, 14, 1-23.

[13] Ellis, R. (1994). The study of second language acquisition. Oxford: Oxford University Press.

[14] Ely, R., \& Gleason, J.B. (2006). I'm sorry I said that: Apologies in young children's discourse. Journal of Child Language, 33, 599-620.

[15] Felix-Brasdefer, J.C. (2003). Declining an invitation: A cross-cultural study of pragmatic strategies in American English and Latin American Spanish. Multilingua, 22, 225-255.

[16] Gordon, D., \& Ervin-Tripp, S. (1984). The structure of children's requests. In R. Schiefelbusch \& J. Pickar (Eds.), The acquisition of communicative competence (pp. 295-321). Baltimore, MD: University Park Press.

[17] Hassell, T. (2003). Requests by Australian learners of Indonesian. Journal of Pragmatics, 35, 1903-1928.

[18] House, J. (1996). Developing pragmatic fluency in English as a foreign language: Routines and metapragmatic awareness. Studies in Second Language Acquisition, 18, 225-252.

[19] House, J., \& Kasper, G. (1981). Politeness markers in English and German. In F. Coulmas (Ed.), Conversational routine: Explorations in standardized communication situations and prepatterened speech (pp. 157-185). The Hague: Mouton de Gruyter.

[20] Hymes, D. (1972). Models of the interaction of language and social life. In J.J. Gumperz \& Dell Hymes (Eds.), Directions in Sociolinguistics. (pp. 35-71). New York: Holt, Reinhart \& Winston.

[21] Kasper, G. (1997). The role of pragmatics in language teaching education. In K. Bardovi-Harlig \& B. Hartford (Eds.), Beyond methods: Components of second language teacher education. New York: McGraw-Hill.

[22] Kasper, G. (1989). Variation in interlanguage speech act realization. In S. Gass, C. Madden, D. Preston, \& L. Selinker (Eds.), Variation in second language acquisition, Vol. 1: Discourse and pragmatics (pp. 37-58). Clevedon, Avon: Multilingual Matters.

[23] Kasper, G., \& Blum-Kulka (Eds.) (1993). Interlanguage Pragmatics. New York: Oxford University Press.

[24] Kasper, G., \& Schmidt, R. (1996). Developmental issues in interlanguage pragmatics. Studies in Second Language Acquisition, $18,149-169$.

[25] Kobayashi, H., \& Rinnert, C. (2003). Coping with high imposition requests: High vs. low proficiency EFL students in Japan. In A.M. Flor, E.U. Juan \& A.F. Guerra (Eds.), Pragmatic competence and foreign language teaching (pp. 161-183). Castello de la Plana: Publications de la Univsitat Jaume I.

[26] Leech, G.N. (1983). Principles of pragmatics. London: Longman.

[27] LoCastro, V. (2003). Face, politeness, and indirectness. In V. LoCastro (Ed.), An Introduction to pragmatics (pp. 108-131). Ann Arbor: MI: University of Michigan Press.

[28] Long, M., Adams, L., McLean, M., \& Castaños, F. (1976). Doing things with words: Verbal interaction in lockstep and small group classroom situations. In J. Fanselow \& R. Crymes (Eds.), On TESOL '76 (pp. 137-153). Washington, DC: TESOL.

[29] Lorscher, W., \& Schulze, R. (1988). On polite speaking and foreign language classroom discourse. International Review of Applied Linguistics, 26, 183-189.

[30] Olshtain, E., \& Cohen, A. (1983). Apology: A speech-act set. In N. Wolfson \& E. Judd (Eds), Sociolinguistics and language acquisition. New York: Newbury House.

[31] Olshtain, E., \& Cohen, A. (1989). Speech act behavior across languages. In H. Dechert \& M. Raupach (Eds.), Transfer in language production (pp. 53-67). Norwood, NJ: Ablex.

[32] Peirce, B. N. (1995). Social identity, investment, and language learning. TESOL Quarterly, 29(1), 9-31.

[33] Rose, K. (2000). An exploratory cross-sectional study of interlanguage pragmatic development. Studies in Second Language Acquisition, 22, 27-67.

[34] Schauer, G.A. (2004). May you speak louder maybe? Interlanguage pragmatic development in requests. In S. Foster-Cohen, M.S. Smith, A. Sorace \& M. Ota (Eds.), EUROSLA Yearbook (Vol. 4, pp. 253-273). Amsterdam: John Benjamins.

[35] Silva, A. (2003). The effects of instruction on pragmatics development: Teaching polite refusals in English. Second Language Studies, 22(1), 55-106. 
[36] Tateyama, Y., Kasper, G., Mui, L., Tay, H., \& Thananart, O. (1997). Explicit and implicit teaching of pragmatic routines. In L. Bouton (Ed.), Pragmatics and language learning, monograph series vol. 8 (pp. 163-178). Urbana-Champaign: Division of English as an International Language, University of Illinois, Urbana-Champaign.

[37] Trosberg, A. (1987). Apology strategies in natives/non-natives. Journal of Pragmatics, 11, 147-67.

[38] Trosberg, A. (1995). Interlanguage pragmatics: Requests, complaints and apologies. Berlin: Mouton de Gruyter.

[39] Wildner-Bassett, M. E. (1994). Intercultural pragmatics and proficiency: Polite 'noises' for cultural appropriateness. International Review of Applied Linguistics, 32(1), 3-17.

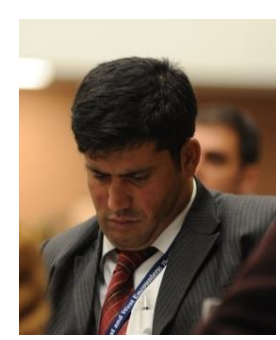

Hasan Aydin received his BA in English and he earned his Master's Degree in Teaching of English to Speakers of Other Languages (MA-TESOL with honorary). He holds his PhD in Curriculum and Instruction emphasizes in Multicultural Education at the University of Nevada, Reno, USA. Currently, he works as a research coordinator for International Kurdish Research Center (UKAM/IKRC), Istanbul, Turkey. His research and academic interests are multicultural education including; cultural integration and assimilation of Turkish immigrants in the EU., and the U.S.; diversity; ethnic identity; Kurdish question in Turkey, and English for second language learners.

Christopher Koch, MA, MSW, is a Ph.D. candidate in Teaching English Speakers to Other Languages (TESOL) at University of Nevada, Reno. His research area is Second Language Acquisition, and Applied linguistics. 